\title{
Editorial
}

\section{Idealism and the information professions}

I am writing this on January 1,1991 . In the last few days of the old year, I have read and heard many depressing summaries of 1990 . The stories are filled with keywords such as recession, homicide, crack cocaine, AIDS, Kuwait and Iraq. Billions of dollars are needed to bail out failed savings and loan institutions. A dangerous generation of children is growing up that never received discipline, values or love from their parents, and who will surely contribute to the violence in our homes and streets. Crumbling infrastructures such as roads, bridges, waterways, public transportation and sanitation systems strain local, state and federal budgets. The decreasing scores on standardized school achievement tests are a testimony to the difficulties teachers face in trying not only to educate but also to care for children who bring to school knives, drugs, hunger and hostilities. Mysterious viruses not only attack and destroy humans and animals, but other kinds of viruses are produced by humans to invade and destroy vital computer data banks. Litigiousness is rampant. Worse, belligerent confrontations over small disputes or insults are increasing and are settled sometimes with guns or knives; suing each other for real or imagined offenses seems quite civilized by comparison. In parts of the world it has been too cold and in others too dry; huge fruit, vegetable and grain crops have been lost. These media stories represent huge challenges for economists, social workers, police officers, engineers, schoolteachers, health professionals, lawyers, lawmakers, public administrators, clergy, diplomats, computer programmers and farmers.

The columnists and commentators also remind us that 1991 , not 1990 , is really the start of the new decade. They characterize the past ten years as the decade of self-gratification, ambition and greed, as exemplified in the extreme by the lifestyle and values of Judy and Sherman McCoy in Tom Wolfe's The bonfire of the vanities. On the brink of the 1990s, there is hope and optimism expressed that those with energy, talent and education will recommit themselves to social consciousness, charity, thrift, understatement and service.

We who are in education for library and information science know that we have been preparing professionals such as these for a long time. Librarians have been ahead of the trend, struggling to eke the most out of inadequate budgets in order to provide meaningful information services. In polls of the general public, librarians rank near the top of the professions as ethical, honest and unself-serving. Librarians have one or more graduate degrees, but have worked extremely hard at modest salaries in order to be able to make satisfying, socially useful contributions to the 
betterment of society. They have taken on the responsibility for keeping homeless street people warm and safe, for watching over unsupervised latchkey children, for teaching illiterates to read, for giving adults who dropped out of school remedial education, for supplying immigrants with information about health, legal and social services, for giving high-risk populations information about AIDS and other diseases, and so on. Despite the moans within the profession about lack of respect, poor salaries and unattractive stereotyping, we as their teachers know that we can take pride in their accomplishments and in their ethical and service ideals.

We may not be doing all we can, however, to prepare our students to face the challenges of the real world. In our courses, seminars and special programs, we owe it to them to lead problem-oriented discussions and explore solutions. Students who are undecided about their long-range plans can be advised to think in terms of public service rather than just about high-tech, profit-oriented information management. If the decade of the nineties really will be different than the eighties, this is the time to let students know about it. Even if they never earn salaries as big as they would in law, business, medicine or engineering, the satisfaction of contributing in a meaningful way to the solution of real-world problems may be more rewarding than money.

Idealism is often thought of as belonging only to the young. It doesn't have to. We old fogies who teach in schools of library and information science should get with the spirit of the new decade and lead, not follow, our students into it.

Trudi Bellardo Associate Editor 